\title{
Kajian Penerimaan e-Learning dengan Pendekatan TAM
}

Conference Paper · April 2017

CITATIONS

0

1 author:

Darmawan Napitupulu

Indonesian Institute of Sciences

25 PUBLICATIONS 18 CITATIONS

SEE PROFILE
READS

5

Some of the authors of this publication are also working on these related projects: 


\title{
KAJIAN PENERIMAAN E-LEARNING DENGAN PENDEKATAN TAM STUDY OF E-LEARNING ACCEPTANCE BASED ON TAM APPROACH
}

\author{
Darmawan Napitupulu ${ }^{1,2}$ \\ 1) Pusat Penelitian Sistem Mutu dan Teknologi Pengujian LIPI \\ 2) Fakultas Ilmu Komputer Universitas Borobudur \\ Email : darwan.na70@gmail.com
}

\begin{abstract}
Advances in science and technology, especially Information and Communication Technology (ICT) more positive impact for the advancement of education today. Various advantages of e-learning to encourage the use of elearning has become a necessity these days is no longer a necessity or compulsion. Utilization of e-learning in the learning process was already inevitable. This study aims to find a picture of the successful implementation of elearning based on user acceptance within the university XYZ. User acceptance can predict the level of utilization of the technology in the future. The method used in this study is a survey with TAM approach that statistically analyzed descriptively. The total number of respondents was 73 people chosen by purposive sampling. The results show the user agrees to the usefulness of e-learning system with a percentage of $69.12 \%$, users also agree with the ease of use of e-learning with a percentage of $69.80 \%$ and the overall user agrees with the acceptance of e-learning system with a percentage of $72.69 \%$.
\end{abstract}

Keywords: e-learning, TAM, user acceptance, ease of use, usefulness

Abstrak

Kemajuan ilmu pengetahuan dan teknologi khususnya Teknologi Informasi dan Komunikasi (TIK) banyak membawa dampak positif bagi kemajuan dunia pendidikan dewasa ini. Berbagai keuntungan e-learning mendorong penggunaan e-learning dewasa ini telah menjadi kebutuhan bukan lagi keharusan atau keterpaksaan. Pemanfaatan sistem e-learning dalam proses pembelajaran pun sudah tidak dapat dielakkan lagi. Penelitian ini bertujuan mengetahui gambaran keberhasilan penerapan e-learning berdasarkan penerimaan pengguna di lingkungan universitas XYZ. Penerimaan pengguna dapat memprediksi tingkat pemanfaatan terhadap teknologi di masa yang akan datang. Metode yang digunakan dalam penelitian ini adalah survei dengan pendekatan TAM yang dianalisis secara statistik deskriptif. Jumlah total respoden adalah 73 orang yang dipilih dengan teknik purposive sampling. Hasil penelitian menunjukkan pengguna setuju dengan kebermanfaatan sistem e-learning dengan persentase sebesar $69.12 \%$, pengguna juga setuju dengan kemudahan penggunaan e-learning dengan persentase $69.80 \%$ dan pengguna secara keseluruhan setuju dengan penerimaan sistem e-learning dengan persentase sebesar $72.69 \%$.

Kata kunci : e-learning, TAM, penerimaan pengguna, kemudahan, kebermanfaatan

\section{PENDAHULUAN}

Kemajuan ilmu pengetahuan dan teknologi khususnya Teknologi Informasi dan Komunikasi (TIK) banyak membawa dampak positif bagi kemajuan dunia pendidikan dewasa ini. Pendidikan formal. informal, dan non formal dapat memanfaatkan TIK untuk menunjang proses pembelajaran kepada para peserta didik. Keunggulan yang ditawarkan bukan saja terletak pada faktor kecepatan dan kemudahan dalam mendapatkan informasi atau sumber materi, namun juga adanya fasilitas multimedia yang dapat membuat proses pembelajaran lebih menarik melalui visual secara interaktif. Berbagai keuntungan e-learning mendorong penggunaan e-learning dewasa ini telah menjadi kebutuhan bukan lagi keharusan atau keterpaksaan. Pemanfaatan sistem e-learning dalam proses pembelajaran pun sudah tidak dapat dielakkan lagi. Berbagai keuntungan yang ditawarkan e-learning tersebut seperti kesempatan belajar yang lebih fleksibel tanpa terikat ruang dan waktu, mempermudah masyarakat mengakses pendidikan, memperkaya materi pembelajaran, menghidupkan proses pembelajaran, membuat proses pembelajaran lebih terbuka, 
meningkatkan efektivitas pembelajaran, serta mendukung peserta didik untuk belajar secara mandiri [1]. Bahkan pengembangan pendidikan menuju e-learning sangat diperlukan dalam rangka meningkatkan standar mutu pendidikan karena e-learning merupakan penggunaan teknologi internet dalam penyampaian pembelajaran [2]. Namun istilah e-learning sebenarnya tidak hanya terbatas pada internet saja, hal ini mengacu pada definisi e-learning berdasarkan Glossary of e-learning Term yang menyebutkan bahwa elearning merupakan sistem pendidikan yang menggunakan aplikasi elektronik untuk mendukung proses belajar-mengajar dengan media internet, jaringan komputer dan komputer standalone [3]. Namun tidak dapat dipungkiri pembelajaran berbasis internet merupakan salah satu manifestasi e-learning yang paling populer saat ini.

Sistem pembelajaran tradisional dicirikan dengan adanya pertemuan antara pelajar dan pengajar untuk melakukan proses belajar mengajar [4]. Perubahan atau pergeseran paradigma sistem pembelajaran mulai tampak pada proses transfer ilmu pengetahuan. Proses pembelajaran yang ada sekarang ini cenderung lebih menekankan pada proses mengajar (teaching), berbasis pada isi (content base), bersifat abstrak serta hanya untuk golongan tertentu (pada proses ini pengajaran cenderung pasif). Seiring dalam perkembangan ilmu dan teknologi ICT, proses dalam pembelajaran mulai bergeser pada proses belajar (learning), berbasis pada masalah (case base), bersifat kontekstual dan tidak terbatas hanya untuk golongan tertentu. Pada proses pembelajaran seperti ini peserta didik dituntut untuk lebih aktif dengan mengoptimalkan sumber-sumber belajar yang ada khususnya melalui Internet.

Pada penelitian sebelumnya [5] telah dilakukan kajian tingkat kesiapan universitas XYZ terhadap implementasi sistem e-Learning dengan menggunakan model ELR (E-Learning Readiness). Berdasarkan 10 faktor ELR yang diidentifikasi, terdapat 5 buah faktor ELR dinyatakan tidak siap yaitu faktor SDM, financial, infrastruktur, inovasi dan institusi. Bahkan secara keseluruhan dapat dikatakan bahwa universitas XYZ berada dalam kategori tidak siap dan membutuhkan peningkatkan (Not ready needs some works). Berdasarkan kondisi kesiapan yang ada, timbul pertanyaan apakah e-learning yang diterapkan akan berhasil atau sebaliknya mengalami kegagalan? Untuk menjawab pertanyaan tersebut, perlu dilakukan penelitian untuk mengetahui bagaimana penerimaan pengguna terhadap teknologi atau sistem e-learning tersebut? Dengan mengetahui tingkat penerimaan pengguna terhadap suatu teknologi, dapat diprediksi tingkat pemanfaatannya. Jika tingkat penerimaan pengguna tinggi maka dapat dipastikan tingkat pemanfaatan terhadap teknologi akan tinggi pula dan jika merujuk teori Delone \& McLean (2003) maka dapat dikatakan implementasi e-learning berhasil [6]. Oleh karena itu dalam penelitian ini dilakukan pengukuran penerimaan pengguna (user acceptance) terhadap sistem e-learning yang diimplementasikan. Dengan demikian diharapkan diperoleh gambaran keberhasilan sistem e-learning berdasarkan persektif pengguna di lingkungan universitas XYZ.

\section{TINJAUAN PUSTAKA}

\subsection{TAM (Technology Acceptance Model)}

Model penerimaan teknologi (Technology Acceptance Model) atau TAM adalah suatu model yang digunakan untuk mengukur sejauh mana tingkat penerimaan pengguna terhadap suatu teknologi khususnya teknologi informasi. Model TAM awalnya dikembangkan oleh Davis (1989) berdasarkan model TRA (Theory of Reasoned Action) untuk menutupi celah (gap) yang menjelaskan faktor-faktor yang mempengaruhi atau mendorong pemakai menggunakan teknologi [7]. Dalam penelitiannya, Davis (1989) mengusulkan dua faktor kunci dari perilaku pengguna teknologi terhadap penerimaan atau adopsi teknologi tersebut. Kedua faktor kunci tersebut adalah kemudahan penggunaan (ease of use) dan kebermanfaatan (usefulness) dimana keduanya diyakini dapat memprediksi sikap atau perilaku dalam menggunakan teknologi [7]. Dengan kata lain, kedua faktor tersebut secara bersama-sama berpengaruh terhadap keinginan menggunakan dan kemudian akan mempengaruhi penggunaan sistem atau teknologi tersebut [7]. Berdasarkan hasil penelitian yang dilakukan, kedua faktor atau variabel tersebut terbukti secara signifikan mempengaruhi penerimaan pengguna terhadap teknologi. Hal ini juga didukung oleh berbagai studi atau penelitian yang lain dimana secara empiris sudah dibuktikan validitasnya [8][9][10][11]. Dengan kata lain model TAM sudah teruji dapat mengukur penerimaan teknologi berdasarkan persepi penggunanya. Model TAM menjadi landasan evaluasi perilaku pengguna dalam menggunakan teknologi yang dapat disajikan pada Gambar 1 berikut ini : 


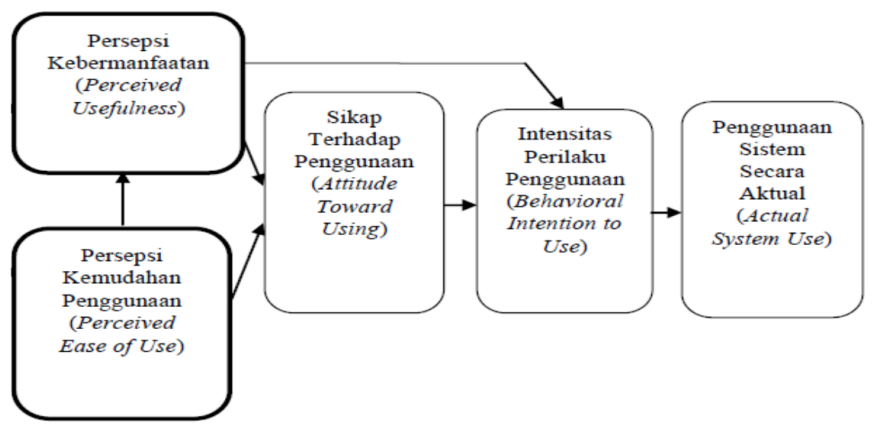

Gambar 1: Technology Acceptance Model [7]

Berdasarkan Gambar 1 di atas dapat dilihat bahwa pemakai teknologi akan mempunyai minat menggunakan teknologi (minat perilaku) jika merasa sistem atau teknologi tersebut bermanfaat dan mudah digunakan. TAM percaya bahwa penggunaan teknologi dapat meningkatkan kinerja seseorang atau organisasi, serta memberikan kemudahan bagi penggunanya dalam menyelesaikan pekerjaannya [12]. Dengan kata lain penyebab penolakan oleh pengguna teknologi dapat diprediksi dari faktor tersebut.

\subsection{PENELITIAN TERKAIT (STATE OF THE ART)}

Model penerimaan teknologi (TAM) merupakan model yang telah digunakan secara luas dalam berbagai domain seperti bisnis, pemerintahan hingga pendidikan yang memanfaatkan teknologi informasi dalam proses bisnisnya. Dalam bidang pendidikan, sudah ada sejumlah peneliti yang menggunakan TAM untuk menjelaskan penerimaan pengguna terhadap teknologi seperti e-learning, teknologi multimedia pembelajaran, perpustakaan digital, e-journal, dll. Dalam konteks e-learning, penelitian yang dilakukan oleh Park (2009) pada sejumlah mahasiswa universitas di Korea terkait minat menggunakan e-learning [13]. Hasil penelitiannya membutikan bahwa TAM merupakan teori yang sesuai untuk memahami penerimaan pengguna e-learning. Kedua variabel yakni kemudahan penggunaan (ease of use) dan kebermanfaatan (usefulness) berpengaruh secara signifikan terhadap minat mahasiswa menggunakan (behavioral intention to use) e-learning. Hasil penelitian menunjukkan bahwa TAM dapat diaplikasikan sebagai teori yang bermanfaat untuk memprediksi penerimaan pengguna terhadap e-learning.

Disamping e-learning, pemanfaatan TAM juga diterapkan pada konteks lain seperti pengembangan teknologi multimedia pembelajaran [14][15]. Pada penelitian Wijaya (2016), dilakukan kajian penerimaan pengguna terhadap teknologi Google (Google Clasroom) pada STT Musi Palembang [15]. Pada konteks perpustakaan digital dan e-journal, beberapa peneliti juga telah menggunakan model TAM untuk meneliti faktor-faktor yang mempengaruhi penerimaan pengguna terhadap perpustakaan digital [16][17]. Menurut Thong (2004), penerimaan seseorang terhadap teknologi perpustakaan digital berpengaruh terhadap tingkat pemanfaatannya di masa mendatang [16]. Berdasarkan teori TAM, tingkat pemanfaatan teknologi akan sangat ditentukan oleh tingkat penerimaan pengguna. Dengan kata lain, penerimaan pengguna akan memprediksi tingkat pemanfaatan.

\section{METODE PENELITIAN}

Pendekatan TAM (Technology Acceptance Model) merupakan pendekatan yang digunakan untuk mengukur sejauh mana tingkat penerimaan pengguna terhadap teknologi e-learning. Survei dilakukan kepada sejumlah responden dengan total sebanyak 85 orang yang ditanyakan tingkat kesetujuannya terhadap setiap variabel dalam TAM. Pemlihan responden dilakukan secara purposive sampling yakni mahasiswa dengan kriteria telah menggunakan sistem e-learning di universitas XYZ. Model TAM seperti yang disebutkan sebelumnya memiliki lima variabel yaitu persepsi kemudahan penggunaan, persepsi manfaat, sikap terhadap penggunaan, minat perilaku penggunaan dan penggunaan sistem aktual [7] Dalam perkembangannya, model TAM mengalami berbagai modifikasi. Gahtani (2001) mengembangkan model TAM dengan menggabungkan variabel minat perilaku penggunaan dengan penggunaan sistem aktual menjadi variabel penerimaan [18]. Oleh karena itu dalam penelitian ini model TAM yang akan digunakan adalah mengikuti Gahtani (2001) yang terdiri dari tiga variabel yakni persepsi kebermanfaatan perceived 
usefulness), persepsi kemudahan penggunaan (perceived ease of use) dan penerimaan (acceptance) seperti pada Tabel 1 berikut ini :

\begin{tabular}{|c|c|c|}
\hline No & Variabel & Indikator \\
\hline \multirow[t]{6}{*}{1.} & \multirow{6}{*}{$\begin{array}{l}\text { Persepsi Kebermanfaatan } \\
\text { (Perceived Usefulness) (X1) }\end{array}$} & Mempercepat pekerjaan $(\mathrm{X} 1.1)$ \\
\hline & & Meningkatkan kinerja $(\mathrm{X} 1.2)$ \\
\hline & & Meningkatkan produktivitas $(\mathrm{X} 1.3)$ \\
\hline & & Efektifitas $(\mathrm{X} 1.4)$ \\
\hline & & Mempermudah pekerjaan (X1.5) \\
\hline & & Bermanfaat $(\mathrm{X} 1.6)$ \\
\hline \multirow[t]{6}{*}{2.} & \multirow{6}{*}{$\begin{array}{l}\text { Persepsi Kemudahan Penggunaan } \\
\text { (Perceived Ease of Use) (X2) }\end{array}$} & Mudah dipelajari (X2.1) \\
\hline & & Dapat dikontrol $(\mathrm{X} 2.2)$ \\
\hline & & Jelas dan dapat dipahami $(\mathrm{X} 2.3)$ \\
\hline & & Fleksibel (X2.4) \\
\hline & & Mudah untuk menjadi terampil $(\mathrm{X} 2.5)$ \\
\hline & & Mudah digunakan $(\mathrm{X} 2.6)$ \\
\hline \multirow[t]{4}{*}{3.} & \multirow[t]{4}{*}{ Penerimaan (Acceptance) (Y) } & Pemakaian Nyata $\left(\mathrm{Y} .1_{1}\right)$ \\
\hline & & Frekuensi Penggunaan $\left(\mathrm{Y}_{\cdot 2}\right)$ \\
\hline & & Kepuasan Pengguna (Y.3) \\
\hline & & Merekomendasikan pengguna lain $\left(\mathrm{Y}_{\cdot 4}\right)$ \\
\hline
\end{tabular}

Instrumen berupa kuesioner penelitian dirancang dengan skala likert yang terdiri dari 4 skala yaitu $1=$ "sangat tidak setuju", 2= "tidak setuju", 3= "setuju" dan 4= "sangat setuju" (likert scale). Teknik analisis data yang digunakan dalam penelitian ini adalah teknik analisis statistik deskriptif dengan langkah-langkah yang dilakukan sebagai berikut [19] :

1. Menentukan besarnya skor kriterium sesuai dengan hasil yang didapat dari pengolahan data sebelumnya. Skor kriterium (SK) adalah skor ideal yang dicapai dalam sebuah penelitian. Apabila diasumsikan seluruh responden (berjumlah 100) yang ditetapkan memilih jawaban angka terendah yaitu 1 untuk 1 pertanyaan, maka skor yang terendah adalah 100. Apabila diasumsikan seluruh responden yang ditetapkan memilih angka tertinggi yaitu 5 untuk 1 pertanyaan, maka skor tertinggi adalah 500. Skor tertinggi inilah yang disebut skor kriterium. Cara mendapatkan skor kriterium ini adalah dengan menggunakan rumus sebagai berikut :

$\sum \mathrm{SK}=$ Skor tertinggi tiap item pertanyaan $\mathrm{x}$ jumlah item pertanyaan $\mathrm{x}$ jumlah responden

2. Kemudian, ditentukan skor total dari hasil pengumpulan data yang sudah dilakukan. Skor total hasil pengumpulan data disimbolkan dengan dengan $\Sigma \mathrm{SH}$.

3. Setelah skor kriterium ( $\left.\sum \mathrm{SK}\right)$ dan skor total hasil pengumpulan data $\left(\sum \mathrm{SH}\right)$ didapatkan, maka dicarilah besarnya presentase $(\mathrm{P})$ jawaban reponden dengan menggunakan rumus sebagai berikut :

Keterangan:

$$
\mathrm{P}=\sum \mathrm{SH} \times 100 \%
$$

$\mathrm{P}=$ Persentase jawaban responden

$\Sigma \mathrm{SK}=$ Skor kriterium

$\Sigma \mathrm{SH}=$ Skor total hasil pengumpulan data

4. Langkah terakhir adalah menentukan rentang hasil berdasarkan skor kriterium dan persentase yang didapatkan untuk kemudian dibandingkan dengan skor hasil pengumpulan data. Rentang (range) hasilnya dapat disajikan pada Tabel 4 berikut ini :

Tabel 2: Kategori jawaban responden

\begin{tabular}{|c|c|}
\hline Persentase (P) & Kategori Jawaban \\
\hline $0-25 \%$ & Sangat Tidak Setuju \\
\hline $26-50 \%$ & Tidak Setuju \\
\hline $51-75 \%$ & Setuju \\
\hline $76-100 \%$ & Sangat Setuju \\
\hline
\end{tabular}




\section{DISKUSI}

\section{IV.1 Validitas dan Reliabilitas Instrumen}

Berdasarkan hasil pengumpulan data, dari 85 data kuesioner hanya terdapat 73 data yang dapat dilanjutkan dalam tahap pengolahan dan analisis data. Dengan kata lain terdapat 12 data kuesioner yang tidak diikutkan dalam tahap selanjutnya karena pengisian data yang tidak lengkap oleh responden. Namun sebelum data kuesioner tersebut dianalisa lebih lanjut, instrumen akan diuji validitas dan reliabilitasnya untuk memastikan bahwa instrumen yang digunakan sudah akurat dan handal. Untuk membuktikan hal tersebut, hasil uji validitas pada penelitian ini mengacu pada besarnya indeks validitas yaitu nilai $\mathrm{r}_{\text {hitung }}$ (corrected item-total correlation). Menurut Azwar (2012), suatu item (pernyataan) dalam instrumen dikatakan valid [20] jika nilai $r_{\text {hitung }}$ lebih besar dari $r_{\text {tabel }}$ dimana Besar $r_{\text {tabel }}$ untuk 73 responden adalah 0.2303.

Tabel 3: Validitas instrumen

\begin{tabular}{|c|c|c|c|}
\hline No & Indikator/Pernyataan & $\begin{array}{c}\text { Corrected Item-Total } \\
\text { Correlation }\left(\mathbf{r}_{\text {hasil }}\right)\end{array}$ & Keterangan \\
\hline \multicolumn{4}{|c|}{ Variabel Persepsi Kebermanfaatan (Perceived Usefulness) (X1) } \\
\hline 1. & Mempercepat pekerjaan $(\mathrm{X} 1.1)$ & 0.649 & VALID \\
\hline 2. & Meningkatkan kinerja $(\mathrm{X} 1.2)$ & 0.670 & VALID \\
\hline 3. & Meningkatkan produktivitas $(\mathrm{X} 1.3)$ & 0.583 & VALID \\
\hline 4. & Efektifitas (X1.4) & 0.432 & VALID \\
\hline 5. & Mempermudah pekerjaan $(\mathrm{X} 1.5)$ & 0.618 & VALID \\
\hline 6. & Bermanfaat (X1.6) & 0.531 & VALID \\
\hline \multicolumn{4}{|c|}{ Variabel Persepsi Kemudahan Penggunaan (Perceived Ease of Use) (X2) } \\
\hline 1. & Mudah dipelajari (X2.1) & 0.663 & VALID \\
\hline 2. & Dapat dikontrol $(\mathrm{X} 2.2)$ & 0.590 & VALID \\
\hline 3. & Jelas dan dapat dipahami $(\mathrm{X} 2.3)$ & 0.603 & VALID \\
\hline 4. & Fleksibel (X2.4) & 0.649 & VALID \\
\hline 5. & Mudah untuk menjadi terampil (X2.5) & 0.610 & VALID \\
\hline 6. & Mudah digunakan $(\mathrm{X} 2.6)$ & 0.686 & VALID \\
\hline \multicolumn{4}{|c|}{ Variabel Penerimaan (Acceptance) (Y) } \\
\hline 1. & Pemakaian Nyata $\left(\mathrm{Y}_{\cdot 1}\right)$ & 0.549 & VALID \\
\hline 2. & Frekuensi Penggunaan $(\mathrm{Y} .2)$ & 0.583 & VALID \\
\hline 3. & Kepuasan Pengguna $\left(\mathrm{Y}_{.3}\right)$ & 0.721 & VALID \\
\hline 4. & Merekomendasikan pengguna lain $\left(\mathrm{Y}_{.4}\right)$ & 0.654 & VALID \\
\hline
\end{tabular}

Berdasarkan pada Tabel 2 di atas dapat dilihat bahwa setiap item (pernyataan) mempunyai nilai ritung lebih besar dari $r_{\text {tabel }}(0.2303)$. Dengan demikian keseluruhan item dapat dikatakan valid karena telah memenuhi persyaratan $(>0.2303)$.

Pengujian reliabilitas kuesioner dalam penelitian ini dilakukan dengan cronbach alpha. Menurut Ghozali (2002), teknik cronbach alpha adalah suatu teknik yang akan menunjukkan indeks konsistensi internal yang akurat, cepat, dan ekonomis. Instrumen dikatakan memenuhi reliabilitas jika nilai cronbach alpha lebih besar dari 0.60. Hasil pengujian reliabilitas kuesioner dapat disajikan pada Tabel 3 sebagai berikut :

Tabel 4: Reliabilitas instrumen

\begin{tabular}{|c|l|c|}
\hline No & \multicolumn{1}{|c|}{ Variabel } & Cronbach Alpha \\
\hline 1. & Persepsi kemudahan Penggunaan (Perceived ease of use) & 0.793 \\
\hline 2. & Persepsi Kebermanfaatan (Perceived usefulness) & 0.823 \\
\hline 3. & Penerimaan (Acceptance) & 0.828 \\
\hline
\end{tabular}

Berdasarkan Tabel 3 dapat ditunjukkan bahwa setiap variabel TAM yaitu persepsi kebermanfaatan, persepsi kemudahan penggunaan dan penerimaan dikatakan telah reliabel. Hal ini dibuktikan dengan nilai cronbach alpha sebagai indeks reliabilitas variabel penerimaan (acceptance) sebesar 0.828, persepsi kebermanfaatan (perceived usefulness) sebesar 0.823 dan persepsi kemudahan pengunaan (perceived ease of use) sebesar 0.793. Secara keseluruhan, indeks reliabilitas yang diperoleh adalah 0.916. Hasilcronbach alpha ini lebih besar dari 0.60 sebagai syarat bahwa instrumen dapat dikatakan reliabel. Dengan demikian instrumen dalam penelitian ini valid dan reliabel karena telah memenuhi persyaratan.

\section{IV.2 Statistik Deskriptif}

Pada bagian ini akan disajikan hasil analisa statistik deskriptif yang dilakukan khususnya untuk mengetahui hasil kuesioner setiap variabel masuk dalam kategori jawaban Sangat Tidak Setuju (STS), Tidak Setuju (TS), Setuju (S) dan Sangat Setuju (SS) yang dapat dilihat sebagai berikut : 


\section{Variabel Kebermanfaatan (Perceived Usefulness)}

- Menentukan besarnya skor kriterium (SK) yang diperoleh :

$\sum \mathrm{SK}=$ Skor tertinggi tiap item pertanyaan $\mathrm{x}$ jumlah item pertanyaan $\mathrm{x}$ jumlah responden

Skor tertinggi tiam item pertanyaan $=4$

Jumlah item pertanyaan $=6$

Jumlah responden $=73$

$\sum \mathrm{SK}=4 \times 6 \times 73=1752$

- Jumlah skor total hasil pengumpulan data variabel kebermanfaatan (X1) :

$\sum \mathrm{SH}=1211$

- Besarnya persentase $(\mathrm{P})$ jawaban responden :

$\mathrm{P}=\frac{\sum \mathrm{SH}}{\sum \mathrm{SK}}=1211 / 1752 \times 100 \%=69.12 \%$

Berdasarkan nilai persentase $(\mathrm{P})$ dan mengacu pada Tabel 4 di atas yakni kategori jawaban responden dapat dilihat bahwa hasil distribusi persentase jawaban responden secara keseluruhan untuk variabel kebermanfaatan (X1) termasuk dalam kategori "Setuju" dengan persentase $69.12 \%$. Implikasinya dalam penelitian ini adalah bahwa pengguna menganggap sistem e-learning yang diimplementasikan sangat bermanfaat dalam mendukung serta meningkatkan proses belajar mengajar. Hal ini mendorong penerimaan pengguna terhadap penerapan e-learning di lingkungan universitas XYZ [7].

\section{Variabel Kemudahan Penggunaan (Perceived Ease of Use)}

- Menentukan besarnya skor kriterium (SK) yang diperoleh : $\sum \mathrm{SK}=$ Skor tertinggi tiap item pertanyaan $\mathrm{x}$ jumlah item pertanyaan $\mathrm{x}$ jumlah responden Skor tertinggi tiap item pertanyaan $=4$

Jumlah item pertanyaan $=6$

Jumlah responden $=73$

$\sum \mathrm{SK}=4 \times 6 \times 73=1752$

- Jumlah skor total hasil pengumpulan data variabel kebermanfaatan (X1) : $\sum \mathrm{SH}=1223$

- Besarnya persentase $(\mathrm{P})$ jawaban responden : $\mathrm{P}=\frac{\sum \mathrm{SH}}{\sum \mathrm{SK}}=1223 / 1752=69.80 \%$

Berdasarkan range kategori yang mengacu pada Tabel 4 di atas dapat dilihat bahwa hasil distribusi persentase jawaban responden secara keseluruhan untuk variabel kemudahan penggunaan (X2) termasuk dalam kategori "Setuju" dengan persentase $69.80 \%$. Implikasinya dalam penelitian ini adalah bahwa pengguna menilai sistem e-learning yang diimplementasikan mudah untuk digunakan dan dioperasikan. Hal ini mendorong penerimaan pengguna terhadap penerapan e-learning di lingkungan universitas XYZ [7].

\section{Variabel Penerimaan (Acceptance)}

- Menentukan besarnya skor kriterium (SK) yang diperoleh :

$\sum \mathrm{SK}=$ Skor tertinggi tiap item pertanyaan $\mathrm{x}$ jumlah item pertanyaan $\mathrm{x}$ jumlah responden

Skor tertinggi tiap item pertanyaan=4

Jumlah item pertanyaan $=4$

Jumlah responden $=73$

$\sum \mathrm{SK}=4 \times 4 \times 73=1168$

- Jumlah skor total hasil pengumpulan data variabel kebermanfaatan (X1) : $\sum \mathrm{SH}=849$

- Besarnya persentase $(\mathrm{P})$ jawaban responden :

$$
\mathrm{P}=\sum \underline{\mathrm{SH}}=849 / 1168=72.69 \%
$$

$$
\sum \mathrm{SK}
$$


Berdasarkan range kategori yang mengacu pada Tabel 4 sebelumnya di atas dapat dilihat bahwa hasil distribusi persentase jawaban responden secara keseluruhan untuk variabel penerimaan (Y) termasuk dalam kategori "Setuju" dengan persentase $72.69 \%$. Implikasinya dalam penelitian ini adalah bahwa berdasarkan persepsi pengguna, sistem e-learning yang diimplementasikan cukup tinggi tingkat penerimaannya (acceptance). Hal ini diperoleh karena faktor kemudahan penggunaan (perceived ease of use) dan kebermanfaatan (perceived usefulness) telah dinilai atau dianggap memadai sebelumnya oleh pengguna. Hasil penelitian ini sejalan dengan penelitian lainnya dimana TAM dapat digunakan untuk memprediksi penerimaan pengguna terhadap teknologi [7][13].

\section{KESIMPULAN}

Berdasarkan penelitian yang telah dilakukan dapat diambil beberapa kesimpulan sebagai berikut :

1. Persepsi kemudahan penggunaan (perceived ease of use) secara keseluruhan, $69.80 \%$ pengguna setuju dengan kemudahan pemakaian sistem e-learning di lingkungan universitas XYZ.

2. Persepsi kebermanfaatan (perceived usefulness) secara keseluruhan, $69.12 \%$ pengguna setuju dengan manfaat sistem e-learning di lingkungan universitas XYZ.

3. Penerimaan pengguna (user acceptance) secara keseluruhan, $72.69 \%$ pengguna setuju dengan penerimaan sistem e-learning di lingkungan universitas XYZ.

4. Hasil analisis menunjukkan bahwa pengguna dalam hal ini mahasiswa menilai bahwa sistem e-learning yang diimplementasikan sangat bermanfaat dan mudah untuk digunakan sehingga dapat meningkatkan penerimaan untuk menggunakan aplikasi tersebut. Dengan demikian jika tingkat penerimaan pengguna tinggi maka dapat diharapkan tingkat pemanfaatan teknologi akan tinggi pula di masa yang akan datang.

5. Saran penelitian lanjutan dapat dikaji secara deskriptif variabel lainnya dari model TAM dan dilakukan analisis secara lebih mendalam untuk melihat seberapa besar pengaruh variabel bebas TAM terhadap penerimaan pengguna.

\section{DAFTAR PUSTAKA}

[1] Sutanta, E. 2010. Konsep dan Implementasi e-Learning (Studi kasus pengembangan e-learning di $\begin{array}{lllll}\text { SMAN } & 1 & \text { Sentolo } & \text { Yogyakarta). }\end{array}$ https://www.researchgate.net/profile/Edhy_Sutanta/publication/228343752_KONSEP_DAN IMPLEMENTASI_E-LEARNING_Studi_Kasus_Pengembangan_ELearning_di_SMA_N_1_Sentolo_Yogyakarta/links/Ofcfd50fc2bf0640e1000000.pdf.

[2] Rosenberg, M. J. 2001. E-learning: Strategies for delivering knowledge in the digital age. New York: McGraw-Hill.

[3] Farhad, S. 2001, "Distance Education : An Introduction". Saba \& Associates. Sumber : http://www.distance-educa-tor.com/portals/research_deintro.html.

[4] Napitupulu, D. 2016. Evaluasi kualitas website universitas XYZ dengan pendekatan Webqual. Buletin Pos dan Telekomunikasi, 14(1), pp: 51-64.

[5] Napitupulu, D. 2016. Kesiapan Implementasi E-Learning di Lingkungan Universitas XYZ. Seminar Nasional Tekno Altek, Pusat Penelitian Inovasi LIPI.

[6] DeLone, W., \& McLean, E. 2003. The DeLone and McLean model of information systems success: A ten-year update, Journal of Management Information Systems, 19(4), pp: 9-30.

[7] Davis, F. D. 1989. Perceived Usefulness, Perceived Ease of Use, and User Acceptance of Information Technology. MIS Quarterly, 13(3), pp: 319-339.

[8] Al-Busaidi, K., \& Al-Shihi, H. 2010. Instructors Acceptance of Learning Management Systems: A Theoretical Framework. Communications of the IBIMA.

[9] Ma, Q., \& Liu, L. 2004. The technology acceptance model: a meta-analysis of empirical findings. Journal of Organizational and End User Computing (JOEUC), 16, pp. 59-72.

[10] Kim, D., \& Chang, H. 2007. Key functional characteristics in designing and operating health information websites for user satisfaction: An application of the extended technology 
acceptance model. International Journal of Medical Informatics, 76, pp: 790-800

[11] Moon, J., \& Kim, Y. 2001. Extending the TAM for a World-Wide-Web context. Information \& Management, 38, pp: 217-230.

[12] Dasgupta, Subhasih, Mary, G., \& Nina, M. 2002. User Acceptance of E-Collaboration Technology: An Extension of the Technology Acceptance Model. Group Decision and Negotiation, 11(2), pp: $87-100$.

[13] Park, S.Y. 2009. An Analysis of the Technology Acceptance Model in Understanding University Students' Behavioral Intention to Use e-Learning. Educational Technology \& Society, Vol.12, No. 3, pp: 150-162.

[14] Syafrizal, A., Ernawati, \& Dwiandiyanta. 2015. Penerapan Model Technology Acceptance Model (TAM) untuk Pemahaman Media Pembelajaran Berbasis Multimedia Interaktif. Scientific Journal of Informatics, 2(1), pp: 9-14.

[15] Wijaya, A. 2016. Analysis of Factors Affecting the Use of Google Classroom to Support Lectures. The 5th ICIBA 2016, International Conference on Information Technology and Engineering Application, pp: 61-68.

[16] Thong, J.Y.L., Wong, W., \& Tam, K.Y. 2004. Determinants of user acceptance of digital libraries: An Empirical Examination of Individual Differences and System Characteristics. Journal of Management Information Systems, 18(3).

[17] Kim, J. 2005. User acceptance of web-based subscription database. Dissertation of Doctor, Tallahassee Florida: Information Studies Department Florida State University.

[18] Gahtani, S.A. 2001. The Applicability of TAM Outside North America: An Empirical Test in United Kingdom. Information Resource Management Journal, pp: 37-46.

[19] Sugiyono. Metode Penelitian Administrasi. Penerbit ALFABETA. Bandung.2012

[20] Azwar, S. 2012. Reliabilitas and Validity. Yogyakarta: Pustaka Pelajar. 